\title{
Emotional Intelligence, Core-Self Evaluation, and Life Satisfaction
}

\author{
Esin Özer1, Erdal Hamarta'2, M. Engin Deniz ${ }^{3}$ \\ ${ }^{1}$ Department of Guidance and Counseling, Faculty of Education, Duzce University, Duzce, Turkey \\ ${ }^{2}$ Department of Guidance and Counseling, Faculty of Education, Necmettin Erbakan University, Konya, Turkey \\ ${ }^{3}$ Department of Guidance and Counseling, Faculty of Education, Yıldız Technical University, İstanbul, Turkey \\ Email: esinozer@duzce.edu.tr
}

Received 27 December 2015; accepted 1 February 2016; published 4 February 2016

Copyright (C) 2016 by authors and Scientific Research Publishing Inc.

This work is licensed under the Creative Commons Attribution International License (CC BY).

http://creativecommons.org/licenses/by/4.0/

c) (†) Open Access

\begin{abstract}
In this study it is aimed to investigate the relationship between emotional intelligence, core self evaluation and life satisfaction of college students and to determine whether emotional intelligence and core self evaluation predict life satisfaction or not. Study was carried out in accordance with relational survey model. The study group contains the students with age ranges vary from 17 to 21. The study group includes the university students of Duzce University's (Turkey) different classes of Faculty of Education, Health Faculty, Faculty of Engineering and Faculty of Management whose ages range from 17 to 21,101 of whom are males $(31.7 \%), 218$ of whom are females (68.3\%), 319 in total, selected with cluster sampling method randomly, and participate in the study voluntarily. In the study, The Life Satisfaction Scale, Trait Emotional Intelligence Questionnaire-SF and The Core-Self Evaluation Scale was used. In the consequence of the analysis, it was observed that, there were significant relations between emotional intelligence, core-self evaluation and life satisfaction. Emotional intelligence and core-self evaluation clarify $34 \%$ of variance in life satisfaction.
\end{abstract}

Keywords

Core-Self Evaluation, Trait Emotional Intelligence, Life Satisfaction

\section{Introduction}

In recent years, positive psychology "which is one of the important study areas of psychology" has come into the prominence. One of the essential parts of the literature of positive psychology is the life satisfaction. The life satisfaction includes the general evaluation about the quality of a person's life with regard to the criteria that he/she chooses. According to Diener and Lucas (1999), life satisfaction includes present life satisfaction, wish of 
changing the life, past satisfaction, future satisfaction, views of the kins of the person about that person's life. Satisfaction areas include job, family, leisure time, health, money, self and the immediate environment of the person. The life satisfaction is regarded as the indicator that the person evaluates his/her life positively and his/her subjective well being. The life satisfaction is closely associated with the positive personal, psychological, social results. For example, individuals with a high life satisfaction encounter better life consequences like economic success, academic success, self-confidence, self-efficacy, mental health, supportive relationships, efficient coping, physical health and the length of lifetime (Suldo \& Huebner, 2006).

Studies made with regard to the emotional intelligence and life satisfaction variables have rather a long and valuable history. The life satisfaction is one of the variables the relation of which with EQ is most noticed (Kong, 2014). Because of the irrevocable importance of person's life quality, many researches have been done regarding the life satisfaction and related emotional, social and behavioral variables (Proctor, Linley, \& Maltby, 2009). In Turkey, there are studies about life satisfaction in the sample of university students examining the factor related to the gender, perceived academic success, perceived economic situation, perceived parents attitude, expectation of the future, religious belief and loneliness (Tuzgöl-Dost, 2007), factors related to well being (Doğan, 2006), subjective and psychological well being (Cenkseven \& Akbaş, 2007), relationship between emotional intelligence and life satisfaction (Deniz \& Y1lmaz, 2004).

The Core Self Evaluation is another variable the relation of which is examined with the life satisfaction. Self is a concept including how the person sees or define him/herself, the evaluations about his/her own values, skills and capacities and how he/she perceives and evaluate the events (Judge, Locke, \& Durnam, 1997). Self evaluation is that the person evaluates his/her functionality and find him/herself successful and valuable and it develops along with coming together of high self-esteem, high self-efficacy, low neuroticism (emotional stability) and internal locus of control (Judge et al., 1997).

a) Self-confidence: it has the broadest field in core-self evaluation and is defined as the value that the person positioned "increasing his/her value". Self-confidence stated as the individual accepts him/herself, has respect for him/herself, trust and believe him/herself, forms a whole of emotions and behaviours. When the person accepts him/herself, he/she can realize the strong aspects of his/her personality and the other aspects that he/she can believe to develop. When he/she values him/herself, he/she adopts an attitude against him/herself (Judge et al., 1997).

b) Self-efficacy: It accounts for a belief to be able to succeed in a job, necessary motivation to succeed in a job and the presence of skills. The self-efficacy is named as the self-belief that he/she can do the job, the belief in different situations that he/she shows a good performance and he/she finds him/herself enough (Judge et al., 1997).

c) Internal locus of control: It represents the belief that the person takes the responsibility of his/her own behaviours and the belief about that he/she controls his/her own environment and the event in his/her life. The individuals having internal locus of control are the people who have strong belief that they control their own lives and they can believe to take responsibility at the high level. The individuals having external locus of control are the people believing that they attribute events to the external factors instead of attributing them to their own control and believe that the chance and the other environmental factors are more important (Judge et al., 1997).

d) Neurotism (lowness in emotional stability): It is a personality trait occuring with a stressed life and increase with the negative emotions like depression. The individuals with a high neuroticism level (emotional instability) choose passive and incompatible strategies to cope with the stress and attribute more negative meanings to the events. The individuals with a low neurotism level exhibit confident, comfortable and calm against the events and involved in the emotional stability (Judge et al., 1997).

Core self evaluation constitutes the valuable reason of some judgments related to life satisfaction, the person's making him/herself feel good making him/her much happier. Individuals with positive self evaluation are the individuals believing they are capable of doing the jobs defining themselve consistently as "positive" and the individuals believing that they control their lives (Judge, Van, \& De Pater, 2004). The individuals with a negative self-evaluation are found to have a low life satisfaction and they are individuals believing that their inability leads to failure and believe that they cannot fulfill the expectations (Judge \& Bono, 2001).

Core-self evaluation (self evaluation) concept has been brought by Judge, Locke and Durham (1997) in literature and has been discussed in many studies. Concerning the subject, there are some studies like core-self evaluation and life satisfaction (Judge, 1998; Piccolo, 2005), emotional intelligence and core-self evaluation (Ahmetoğlu, Leutner, \& Premuzic, 2011; Kluempfer, 2008), the stress perceived in the Spaniard young and 
adult sample, core-self evaluation and life satisfaction (Rey \& Extremera, 2014). Besides, there are core-self evaluation oriented intercultural studies. In cultures except the occidental, for example, core-self evaluation study in Japan stands out (Piccolo et al., 2005).

Studies in Turkey, there has been found a limited number of studies related to core-self evaluation and these studies have been found to be working life and performance oriented (Güven, 2007; Özer \& Tozkoparan, 2013), driver behaviors (Kisbu, 2006) and worker’s core-self evaluation oriented (Akgündüz \& Akdağ, 2014).

Though the emotions are common for all people, individuals differ from each other in using and processing the emotions (Petrides \& Furnham, 2003). In definitions of emotional intelligence, there are some factors such as skills of receive the emotions and explain them and the skills of emotions replacing the logic, using the emotions and understand in order to ease the thoughts and managing the emotions for emotional development (Brackett \& Warner, 2004).

Petrides and Furnham (2000) discuss the emotional intelligence in two different ways as a "characteristic" emotional intelligence and as a "data processing" emotional intelligence. The characteristic of emotional intelligence (TEQ), is regarded as the perceptions towards the core and related to the emotions and placed in the concept of personality and include the personal differences of the individual in the manner of him/her experiences, definitions, understanding, arranging and using about others (Petrides \& Funham, 2001). The characteristic of emotional intelligence emphasizes the personal tendencies in using the perception, processing, arranging and emotional information and includes the qualities related to the person's own internal evaluation (which reveal itself in certain behaviours and characteristics like behaviours consistent in different environments, optimism, secure initiative and empathy).

Emotional intelligence is a factor continuing to grab the attentions of researchers and the literature about emotional intelligence continues to increase. In emotional intelligence studies, there are variables like leadership and career (Di Fabio \& Saklofske, 2014), protective role of emotional intelligence in physical and mental health (Andrei \& Petrides, 2013), behavioural problemin adolescents (Gugliandolo, Costa, Cuzzocrea, Larcan, \& Petrides, 2015), decision making mechanisms (Di Fabio \& Blueste, 2010), self efficacy (Di Fabio \& Palazzeschi, 2008), relationship with core-self evaluation relation (Ahmetoğlu et al., 2011), psychological resilience (Armstrong, Galligan, \& Critchley, 2011) and social support (Di Fabio \& Kanny, 2012).

According to the findings in the studies, emotional intelligence increases the level of transducer strategies. The individuals with a high emotional intelligence can cope with stress better and have broader social networks and can have higher grader by reducing the negative effect of the pressure in academic performance (Petrides et al., 2004). The individuals with high emotional intelligence are the ones easing the life satisfaction and subjectively being good and have the capacity of receiving, using, understanding and managing both his/her own emotions and the others' emotions. lndividuals with high emotional intelligence have more sufficient coping mechanism to cope with the situation and see the situation as a development opportunity for themselves intstead of seeing it as a threat (Mikolajczak \& Limunet, 2008).

The feature of high emotional intelligence helps the individuals choose the transducer strategies, reduce the negative feelings and replacing the positive emotions. Against the troublesome events and situations, individuals with high intelligence experience less stress than those with low emotional intelligence, in the time of exam, the individuals with high EQ, show psychological symptoms and somatic complaints lesser than those with low EQ. (Mikolojczak \& Limunet, 2008).

Individuals with high emotional intelligence are more successful at regulating their emotions and evaluating the social clues, better at providing the encouragement in social relations and they are accepted more by the others (Mavroveli, Petrides, Sangareau, \& Funham, 2009). There are some studies which point out the relationship between life satisfaction and EQ (Extremera \& Berracol, 2005; Deniz \& Y1lmaz, 2004; Palmer, Donaldson, \& Stugh, 2002). It is aimed to make contribution to the literature along with adding the variable "core-self (self) evaluation" to the study. In Turkey, in studies regarding "core self evaluation" some researches sampling individuals working in different institutions stands out (Güven, 2007; Özer \& Tozkoparan, 2013), core-self evaluations of workers (Akgündüz \& Akdağ, 2014), driver behaviours (Kisbu, 2006). It is aimed to make contribution to the field in that it is a study in the sample of university students in this study.

\section{Method}

\subsection{The Model of the Study}

The study has been carried out in accordance with relational survey model. 


\subsection{The Study Group}

The study group consists of 319 university students in total whose ages range from 17 to 21, 101 (31.7\%) of whom are males and 218 (68.3\%) are girls studying in different classes of Faculty of Education, Health Faculty, Faculty of Engineering and Faculty of Management at Duzce University (Turkey), selected with random cluster sampling method and participate in the study voluntarily.

\subsection{Data Collection Instruments}

The students constituting the working group are selected randomly and participated in the study voluntarily. The Life Satisfaction Scale (Köker, 1991), Trait Emotional Intelligence Questionnaire-SF (Deniz, Özer, \& Işık, 2013) and The Core-Self Evaluation Scale (Kisbu, 2006), personal information form have been applied together. Before the application, related instructions have been read and informed about the application.

\subsubsection{The Life Satisfaction Scale}

The Life satisfaction scale which was developed by Diener, Emmons, Laresen and Griffin (1985) was adapted to Turkish by Köker (1991). The scale is composed of five materials concerning life satisfaction. Each material is specified according to 7 graded answering system (1: not applicable, 7: very applicable). Test-retest reliability coefficient of scale was founded as 0.85 and material-test correlation was founded between 0.71 and 0.81 . The highest point to be gotten from the life satisfaction scale is 35 and the lowest point is 5 . Getting a low point from the scale is regarded as the indicator of a low life satisfaction.

\subsubsection{Trait Emotional Intelligence Questionnaire-SF}

Trait Emotional Intelligence Questionnaire-SF form was developed by Petrides and Furnharm and it was adapted to Turkish by Deniz, Özer and Ișık (2013). This form aiming to specify the individuals' perception level related to the "emotional proficiency" can be applied within groups and individually. High point gotten from the total of the scale indicates that emotional proficiencies are perceived high and the low points indicates that emotional proficiencies are perceived low. Language validity and equivalence of scale was supported by the positive correlations through the points gotten from Turkish forms. ln consequence of explanatory factor analysis in order to examine structure validity of the scale, a four factor structure (being good, self-control, sensuality and socialness) with 20 materials were obtained. The results of confirmatory factor analysis with the purpose of understanding whether the this structure obtained according nicely to the sample data showed that the sample accord in which the scale was applied was good. The all of the internal consistency reliability coefficient scale of TEQue-SF was founded as 0.81 and test-retest reliability coeffienct was found as 0.86 .

\subsubsection{The Core-Self Evaluation Scale}

The core-self evaluation scale which is developed by Judge, Erez, Joyce and Thoresen (2003) and adapted to Turkish by Kisbu (2006). Self-efficacy, self respect, internal locus of control and neurotism dimensions are explained with totally 12 statements.

Explanatory factor analysis is applied to determine the structural validity of The Core-Self Evaluation Scale. Ln factor analysis, Kaiser-Meyer-Olkin sample value occurs with a level of 0.811; test result of Barlett 5154.844 and $p<0.05$. Core self evaluation is represented with 12 statements under four factors and it is determined that the factor groups are self esteem, self efficacy, locus of control and neurotism and determined that clarification rate of total variance is about $65.451 \%$.

The validity of five factor structure obtained by explanatory factor analysis of core-self evaluation has been tested by confirmatory factor analysis. It was found that the core-self evaluation scale of $t$ values related to the variables observed in the consequence of DFA results varied between the 8.06 and 18.34 and standardised analysis values varied between 0.75 to 0.91 .

Besides, $\mathrm{X}^{2}$ value was discovered as $\left(\mathrm{X}^{2} / \mathrm{df}\right) 3.24 \mathrm{RMSEA}=0.034 \mathrm{GFI}=0.93$ and $\mathrm{AGFI}=0.89$ and $\mathrm{CFI}=$ 0.98 depending upon $=9.71 \mathrm{df}=3$ normalized chi-square values. The general reliability value of scale was calculated as $\alpha=0.754$.

\subsubsection{Personal Information Form}

The information related to the students' personal qualities in sample group are obtained by the information form. 
A personal information form is prepared by the researcher in an attempt to determine the students' demographic features like gender, department, class etc.

\subsubsection{Analysis of Data}

Statistical analysis of data, Pearson product-moment correlation coefficient has been used in determining the relations between life satisfaction, emotional intelligence and core-self evaluation. Multiple regression analysis technique (Enter) has been used in an attempt to determine whether the emotional intelligence and core-self evaluation predict the life satisfaction or not.

\section{Findings}

Correlation results about the relation between life satisfaction, emotional intelligence and core-self evaluation (Table 1) and emotional intelligence and core-self evaluation predicting the life satisfaction is presented in (Table 2).

When Table 1 is examined, it can be seen that there is a relation between emotional intelligence and core-self evaluation. According to Table 1, life satisfaction has a positive relations with emotional intelligence and core-self evaluation $(p<0.05)$.

When Table 2 is examined, it is examined with multiregression analysis whether the emotional intelligence and core-self evaluation predicts the life satisfaction in a significant way or not.

In the result of this analysis, it has been observed that there are significant relations between emotional intelligence and core-self evaluation and life satisfaction $(\mathrm{R}=0.586, p<0.01 ; \mathrm{F}=20.187, p<0.01)$. Emotional intelligence and core-self evaluation clarifies $34 \%$ of variance in life satisfaction. When the beta values are examined, respecting whether which variables predict life satisfaction, it has been observed that well being which is in the sub-dimension of emotional intelligence $(\beta=0.460, p<0.01)$, self esteem which is in the sub-dimensions of core-self evaluation $(\beta=0.182, p<0.01)$ and sociability which is in the sub-dimension of emotional intelligence $(\beta=0.139, p<0.01)$.

\section{Discussion}

There are few studies searching the corrrelation between core self evaluation, emotional intelligence and life satisfaction. The finding, which there is a relation between emotional intelligence and core-self evaluation, obtained in the study shows similar consequences to those former ones related to the issue (Judge 1997; Judge et al., 1998; Judge et al., 2003; Song, 2013).

The finding showing that there is a relation between emotional intelligence and core-self evaluation resembles to those in other studies. Core-self evaluation is highly associated with EQ evaluations (Brackett \& Mayer, 2003). There is a strong connection between TEQ and core-self evaluation. If the person has a high core-self evaluation, he/she also have a high emotional intelligence (Kluemper, 2008).

Table 1. The relationship between life satisfaction, emotional intelligence and core-self evaluation.

\begin{tabular}{|c|c|c|c|c|c|c|c|c|c|c|}
\hline & & LS & $\begin{array}{l}\text { Well } \\
\text { being }\end{array}$ & Self control & Emotionality & Sociability & $\begin{array}{c}\text { Self } \\
\text { esteem }\end{array}$ & $\begin{array}{c}\text { Self } \\
\text { efficacy }\end{array}$ & $\begin{array}{c}\text { Locus of } \\
\text { control }\end{array}$ & Neuroticism \\
\hline $\begin{array}{l}\text { Life Satisfaction } \\
\text { (LS) }\end{array}$ & $\mathrm{r}$ & 1 & $0.530^{* *}$ & $0.165^{* *}$ & $0.233^{* *}$ & $0.114^{*}$ & $0.424^{* *}$ & $0.234^{* *}$ & $0.283^{* *}$ & $0.316^{* *}$ \\
\hline Well being & $\mathrm{r}$ & $0.530^{* *}$ & 1 & $0.312^{* *}$ & $0.355^{* *}$ & $0.417^{* *}$ & $0.514^{* *}$ & $0.408^{* *}$ & $0.403^{* *}$ & $0.347^{* *}$ \\
\hline Self control & $\mathrm{r}$ & $0.165^{* *}$ & $0.312^{* *}$ & 1 & $0.345^{* *}$ & $0.282^{* *}$ & $0.297^{* *}$ & $0.439^{* *}$ & $0.348^{* *}$ & $0.461^{* *}$ \\
\hline Emotinality & $\mathrm{r}$ & $0.233^{* *}$ & $0.355^{* *}$ & $0.345^{* *}$ & 1 & $0.319^{* *}$ & $0.258^{* *}$ & $0.274^{* *}$ & $0.240^{* *}$ & $0.266^{* *}$ \\
\hline Sociability & $\mathrm{r}$ & $0.114^{*}$ & $0.417^{* *}$ & $0.282^{* *}$ & $0.319^{* *}$ & 1 & $0.264^{* *}$ & $0.392^{* *}$ & $0.346^{* *}$ & $0.139^{*}$ \\
\hline Self esteem & $\mathrm{r}$ & $0.424^{* *}$ & $0.514^{* *}$ & $0.297^{* *}$ & $0.258^{* *}$ & $0.264^{* *}$ & 1 & $0.514^{* *}$ & $0.517^{* *}$ & $0.489^{* *}$ \\
\hline Self efficacy & $\mathrm{r}$ & $0.234^{* *}$ & $0.408^{* *}$ & $0.439^{* *}$ & $0.274^{* *}$ & $0.392^{* *}$ & $0.514^{* *}$ & 1 & $0.563^{* *}$ & $0.475^{* *}$ \\
\hline Locus of control & $\mathrm{r}$ & $0.283^{* *}$ & $0.403^{* *}$ & $0.348^{* *}$ & $0.240^{* *}$ & $0.346^{* *}$ & $0.517^{* *}$ & $0.563^{* *}$ & 1 & $0.351^{* *}$ \\
\hline \multirow{2}{*}{ Neuroticism } & $\mathrm{r}$ & $0.316^{* *}$ & $0.347^{* *}$ & $0.461^{* *}$ & $0.266^{* *}$ & $0.139^{*}$ & $0.489^{* *}$ & $0.475^{* *}$ & $0.351^{* *}$ & 1 \\
\hline & $\mathrm{N}$ & 319 & 318 & 319 & 319 & 319 & 319 & 319 & 319 & 319 \\
\hline
\end{tabular}


Table 2. Emotional intelligence and core-self evaluation predicting the life satisfaction.

\begin{tabular}{cccccc}
\hline Independent variables & $\mathrm{R}$ & $\mathrm{R}^{2}$ & $\mathrm{~F}$ & $\beta$ & $\mathrm{t}$ \\
\hline Wellbeing & $0.586^{\mathrm{a}}$ & 0.343 & $20.187^{*}$ & $0.460^{*}$ & $7.817^{*}$ \\
Self control & & & -0.053 & -0.949 \\
Emotionality & & & 0.058 & 1.114 \\
Sociability & & $-0.139^{*}$ & $-2.551^{*}$ \\
Self esteem & & $0.182^{*}$ & $2.879^{*}$ \\
Self efficacy & & -0.068 & -1.070 \\
Locus of control & & & 0.053 & 0.890 \\
Neuroticism & & & 0.107 & 1.814 \\
\hline
\end{tabular}

In another study (Ahmetoğlu et al., 2011) it has been found that if a person has a high core-self evaluation, he/she has a high emotional intelligence. Individuals with high EQ have much more positive self evaluation, high self-confidence, effectiveness and psychological powerfulness. Individuals with high EQ are effective in showing their performance, have much more life satisfaction and less depression (Petrides et al., 2007). A negative relation is found between TEQ and depressive symptoms, anxiety, somatic complaints, negative mood and socioemotional inability (Petrides, 2007).

When Table 2 is examined, it has been observed that there are significant relations between emotional intelligence and core-self evaluation and life satisfaction $(\mathrm{R}=0.586, p<0.01 ; \mathrm{F}=20.187, p<0.01)$. Emotional intelligence and core-self evaluation clarifies $34 \%$ of variance in life satisfaction. The finding resembles to those in other studies. The study carried out by Srivastava, Locke, Judge and Adams (2010), it is concluded that there is a relation between life satisfaction and core-self evaluation.

In the study of Dong, Urista and Gondrun (2008), it has been concluded that emotional intelligence and self-confidence is associated with life satisfaction. It has been found that individuals with high emotional intelligence have also a high self-esteem (Frazier, 2004).

Individuals with high core-self evaluation consider themselves as the individuals who are talented, proficient and controls their own life. This evaluation creates the basis resources reducing the harmful results of stres and facilitates subjectively being good (Kammeyer-Mueller, 2009; Judge 2004).

In a study carried out with college students in Hong Kong, an important positive correlation has been found between life satisfaction and self-confidence (Kwan, Bond, \& Singelis, 1997). In intercultural study carried out between Japan and America, it has been concluded that positive self evaluation increases life satisfaction (Piccolo, 2005). Core-self evaluation plays an intermediary role in EQ and life satisfaction (Kong, 2014).

The relationship between emotional intelligence and life satisfaction finding is supported by other studies. There are some studies which point out the relationship between life satisfaction and EQ (Extremera \& Berracol, 2005; Deniz \& Y1lmaz, 2004). Emotional intelligence mediates between awareness, high positive sensation and high life satisfaction (Schutte \& Malouff, 2011).

\section{Suggestions}

This study is conducted at Duzce University. In the future studies, students who are studying in the various public and private universities in the different cities can be included. Besides, the same study can be conducted with different groups such as nurses, teachers etc. Psychological interventions, helping individual develop his/her own life satisfaction and evaluate his/her own value, effectiveness and competence is a valuable service which is the basis of the applications for the person increasing subjective well being. With the purpose of increasing the person's sources and positive development, developing psychological intervention programs in different level and different groups creates important resources for the academicians and experts working in the field.

\section{References}

Ahmetoğlu, G., Leutner, F., \& Chamorro-Premuzic, T. (2011). EQ-Nomics: Understanding the Relationship between Individual Differences in Trait Emotional Intelligence and Entrepreneurship. Personality and Individual Differences, 51, 
1028-1033. http://dx.doi.org/10.1016/j.paid.2011.08.016

Akgündüz, Y., \& Akdağ, G. (2014). İşgörenlerin Kişilik Özelliklerinin Temel Benlik Değerlendirmelerine ve İşten Ayrılma Niyetlerine Etkisi. Yönetim Bilimleri Dergisi, 12, 295-318.

Andrei, F., \& Petrides, K. V. (2013). Trait Emotional Intelligence and Somatic Complaints with Reference to Positive and Negative Mood. Psihologija, 46, 5-15. http://dx.doi.org/10.2298/PSI1301005A

Armstrong, A. R., Galligan, R. F., \& Critchley, C. R. (2011). Emotional Intelligence and Psychological Resilience to Negative Life Events. Personality and Individual Differences, 51, 331-336. http://dx.doi.org/10.1016/j.paid.2011.03.025

Brackett, J., \& Warner, R. (2004). EQ and Its Relation to Everyday Behaviour. Personality and Individual Differences, 36, 1387-1402. http://dx.doi.org/10.1016/S0191-8869(03)00236-8

Brackett, M. A., \& Mayer, J. D. (2003). Convergent, Discriminant and Incremental Validity of Competing Measures of Emotional Intelligence. Personality and Social Psychology Bulletin, 29, 1147-1158. http://dx.doi.org/10.1177/0146167203254596

Cenkseven, F., \& Akbaş, T. (2007). Üniversite öğrencilerinde öznel ve psikolojik iyi olmanın yordayıcılarının incelenmesi. Türk Psikolojik Danışma ve Rehberlik Dergisi, 3, 43-65.

Deniz, M. E., \& Y1lmaz, E. (2004). The Relationship between the Emotional Intelligence Abilities and Life Satisfaction of the University Students. 8th National Education Sciences Congress, 6-9 February 2004, Malatya: Inonu University, Faculty of Education.

Deniz, M. E., Özer, E., \& Işık, E. (2013). Trait Emotional Intelligence Questionnaire—Short Form: Validity and Reliability Studies. Eğitim ve Bilim, 38, 169, 407-419.

Di Fabio, A., \& Blustein, D. L. (2010). Emotional Intelligence and Decisional Conflict Styles: Some Empirical Evidence among Italian High School Students. Journal of Career Assessment, 18, 71-81. http://dx.doi.org/10.1177/1069072709350904

Di Fabio, A., \& Kenny, M. E. (2012). The Contribution of Emotional Intelligence to Decisional Styles among Italian High School Students. Journal of Career Assessment, 20, 404-414. http://dx.doi.org/10.1177/1069072712448893

Di Fabio, A., \& Palazzeschi, L. (2008). Emotional Intelligence and Self-Efficacy in a Sample of Italian High School Teachers. Social Behavior and Personality, 36, 315-326. http://dx.doi.org/10.2224/sbp.2008.36.3.315

Di Fabio, A., \& Saklofske, D. H. (2014). Comparing Ability and Self-Report Trait Emotional Intelligence, Fluid Intelligence and Personality Traits in Career Decision. Personality and Individual Differences, 64, 174-178.

http://dx.doi.org/10.1016/j.paid.2014.02.024

Diener, E., Emmons, R. A., Larsen, R. J., \& Griffin, S. (1985). The Satisfaction with Life Scale. Journal of Personality Assessment, 49, 71-75. http://dx.doi.org/10.1207/s15327752jpa4901_13

Diener, E., Suh, E. M., Lucas, R. E., \& Smith, H. E. (1999). Subjective Well-Being: Three Decades of Progress. Psychological Bulletin, 125, 276-302. http://dx.doi.org/10.1037/0033-2909.125.2.276

Doğan, T. (2006). Üniversite öğrencilerinin iyilik halinin incelenmesi. Hacettepe Üniversitesi Eğitim Fakültesi Dergisi, 30, 20-129.

Dong, O., Urista, M., \& Gundrum, D. (2008). The Impact of Emotional Intelligence, Self-Esteem, and Self-Image on Romantic Communication over MySpace. Cyber Psychology \& Behavior, 11, 577-578. http://dx.doi.org/10.1089/cpb.2007.0154

Dost, T. M. (2007). Üniversite Öğrencilerinin Yaşam Doyumunun Bazı Değişkenlere Göre İncelenmesi. Pamukkale Üniversitesi Ĕ̌itim Fakültesi Dergisi, 22, 132-142.

Extremera, N., \& Berracol, F. (2005). Perceived Emotional Intelligence and Life Satisfaction: Predictive and Incremental Validity Using the Trait Meta-Mood Scale. Personality and Individual Differences, 39, 937-948. http://dx.doi.org/10.1016/j.paid.2005.03.012

Frazier, P. A., Tix, A. P., \& Barron, K. E. (2004). Testing Moderator and Mediator Effects in Counseling Psychology Research. Journal of Counseling Psychology, 51, 115-134. http://dx.doi.org/10.1037/0022-0167.51.1.115

Gugliandolo, M. C., Costa, S., Cuzzocrea, F., Larcan, R., \& Petrides, K. V. (2015). Trait Emotional Intelligence and Behavioral Problems among Adolescents: A Cross-Informant Design. Personality and Individual Differences, 74, 16-21.

http://dx.doi.org/10.1016/j.paid.2014.09.032

Güven, L. (2007). The Effect of Positive Core Self and External Evaluations on Performance Appraisals. Unpublished Master's Thesis, Ankara: Middle East Technical University, School of Social Sciences.

Judge, T. A., \& Bono, J. E. (2001). Relationship of Core Self-Evaluations Traits-Self-Esteem, Generalized Self Efficacy, Locus of Control and Emotional Stability with Job Satisfaction and Job Performance: A Meta-Analysis. Journal of Applied Psychology, 86, 80-92. http://dx.doi.org/10.1037/0021-9010.86.1.80 
Judge, T. A., Bono, J. E., Erez, A., \& Locke, E. A. (2005). Core Self-Evaluations and Job and Life Satisfaction: The Role of Self-Concordance and Goal Attainment. Journal of Applied Psychology, 90, 257-268. http://dx.doi.org/10.1037/0021-9010.90.2.257

Judge, T. A., Erez, A., \& Bono, J. E. (1998). The Power of Being Positive: The Relation between Positive Self-Concept and Job Performance. Human Performance, 11, 167-187. http://dx.doi.org/10.1080/08959285.1998.9668030

Judge, T. A., Erez, A., Joyce, E. B., \& Thoresen, C. (2003). The Core Self-Evaluations Scale: Development of a Measure. Personnel Psychology, 56, 303-331. http://dx.doi.org/10.1111/j.1744-6570.2003.tb00152.x

Judge, T. A., Locke, E. A., \& Durham, C. C. (1997). The Dispositional Causes of Job Satisfaction: A Core Evaluations Approach. Research in Organizational Behavior, 19, 151-188.

Judge, T. A., Van, V. A. M., \& De Pater, I. (2004). Emotional Stability, Core Self-Evaluations, and Job Outcomes: A Review of the Evidence and an Agenda for Future Research. Human Performance, 17, 325-346. http://dx.doi.org/10.1207/s15327043hup1703_4

Kammeyer-Mueller, J. D., Judge, T. A., \& Scott, B. A. (2009). The Role of Core Self-Evaluations in the Coping Process: Testing an Integrative Model. Journal of Applied Psychology, 94, 177-195. http://dx.doi.org/10.1037/a0013214

Kisbu, Y. (2006). Influences of Regulatory Focus, Core Self-Evaluations and Age on Biases in Perception and Choice. Unpublished Master’s Thesis, Istanbul: Koç University, School of Social Sciences.

Kluemper, D. H. (2008). Trait Emotional Intelligence: The Impact of Core-Self Evaluations and Social Desirability. Personality and Individual Differences, 44, 1402-1412. http://dx.doi.org/10.1016/j.paid.2007.12.008

Köker, S. (1991). Normal ve Sorunlu Ergenlerin Yaşam Doyumu Düzeyinin Karşılaştırllması. Unpublished Master’s Thesis, Ankara: Ankara University/School of Social Sciences.

Kong, F., Wang, X., \& Zhao, J. (2014). Dispositional Mindfulness and Life Satisfaction: The Role of Core Self-Evaluations. Personality and Individual Differences, 56, 165-169. http://dx.doi.org/10.1016/j.paid.2013.09.002

Kwan, V. S. Y., Bond, M. H., \& Singelis, T. M. (1997). Pancultural Explanations for Life-Satisfaction: Adding Relationship Harmony to Self-Esteem. Journal of Personality and Social Psychology, 73, 1038-1051. http://dx.doi.org/10.1037/0022-3514.73.5.1038

Mavroveli, S., Petrides, K. V., Sangareau, Y., \& Furnham, A. (2009). Exploring the Relationships between Trait Emotional Intelligence to Objective Socio-Emotional Outcomes in Childhood. British Journal of Educational Psychology, 9, 259272. http://dx.doi.org/10.1348/000709908X368848

Mikolajczak, M., \& Limunet, O. (2008). TEQ and the Cognitive Appraisal of Stressful Events: An Exploratory Study. Personality and Individual Differences, 44, 144-153. http://dx.doi.org/10.1016/j.paid.2007.12.012

Özer, P., \& Tozkoparan, G. (2013). Öz Benlik Değerlendirmeleri ile İş ve Yaşam Doyumu İlişkisinin Sorgulanmasına Yönelik Görgül Bir Araştırma. Journal of Yasar University, 30, 4933-4947.

Petrides, K. V., \& Furnham, A. (2000). On the Dimensional Structure of Emotional Intelligence. Personality and Individual Differences, 29, 313-320. http://dx.doi.org/10.1016/S0191-8869(99)00195-6

Petrides, K. V., \& Furnham, A. (2001). Trait Emotional Intelligence: Psychometric Investigation with Reference to Established Trait Taxonomies. European Journal of Personality, 15, 425-448. http://dx.doi.org/10.1002/per.416

Petrides, K. V., Fredericson, N., \& Furnham, A. (2004). The Role of Trait EQ in Academic Performance and Deviant Behaviours at School. Personality and Individual Differences, 36, 277-293. http://dx.doi.org/10.1016/S0191-8869(03)00084-9

Petrides, K. V., Pita, R., \& Kokkinaki, F. (2007). The Location of Trait Emotional Intelligence in Personality Factor Space. British Journal of Psychology, 98, 273-289. http://dx.doi.org/10.1348/000712606X120618

Petrides, K., \& Furnham, A. (2003). Trait Emotional Intelligence: Behavioural Validation in Two Studies of Emotion Recognition and Reactivity to Mood Induction. European Journal of Personality, 17, 39-57.

http://dx.doi.org/10.1002/per.466

Piccolo, R. F., Judge, T., Takahashi, K., Watanabe, N., \& Locke, E. A. (2005). Core Self-Evaluations in Japan: Relative Effects on Job Satisfaction, Life Satisfaction, and Happiness. Journal of Organizational Behavior, 26, 965-984. http://dx.doi.org/10.1002/job.358

Proctor, C. L., Linley, P. A., \& Maltby, J. (2009). Youth Life Satisfaction: A Review of the Literature. Journal of Happiness Studies, 10, 583-630. http://dx.doi.org/10.1007/s10902-008-9110-9

Rey, L., \& Extremera, N. (2014). Core Self-Evaluations, Perceived Stress and Life Satisfaction in Spanish Young and Middle-Aged Adults: An Examination of Mediation and Moderation Effects. Social Indicators Research, 120, 515-524. http://dx.doi.org/10.1007/s11205-014-0601-2

Schutte, N. S., \& Malouff, J. M. (2011). Emotional Intelligence Mediates the Relationship between Mindfulness and Subjective Well-Being. Personality and Individual Differences, 50, 1116-1119. 
http://dx.doi.org/10.1016/j.paid.2011.01.037

Song, G., Kong, F., \& Jin, W. (2013). Mediating Effects of Core Self-Evaluations on the Relationship between Social Support and Life Satisfaction. Social Indicators Research, 114, 1161-1169. http://dx.doi.org/10.1007/s11205-012-0195-5

Srivastava, A., Locke, A. E., Judge, T. A., \& Adams, J. (2010). Core Self-Evaluations as Causes of Satisfaction: The Mediating Role of Seeking Task Complexity. Journal of Vocational Behavior, 77, 255-265. http://dx.doi.org/10.1016/j.jvb.2010.04.008

Suldo, S., \& Huebner, S. (2006). Is Extremely High Life Satisfaction During Adolescence Advantageous? Social Indicators Research, 78, 179-203. http://dx.doi.org/10.1007/s11205-005-8208-2 